\title{
A POSSIBILITY OF DETERMINING THE AUTHENTICITY OF ORGANIC WHEAT USING GC-MS
}

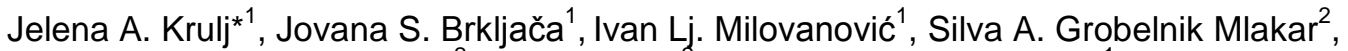 \\ Martina Bavec ${ }^{2}$, Franc Bavec ${ }^{2}$, Marija I. Bodroža Solarov ${ }^{1}$ \\ ${ }^{1}$ University of Novi Sad, Institute for Food Technology, 21000 Novi Sad, \\ Bulevar cara Lazara 1, Serbia \\ ${ }^{2}$ University of Ljubljana, Biotechnical Faculty, Agronomy Department, Chair for Fruit, Wine and \\ Vegetable Growth, Ljubljana, Jamnikarjeva 101, Slovenia
}

\author{
${ }^{*}$ Corresponding author: \\ Phone: +381214853798 \\ E-mail address: jelena.krulj@fins.uns.ac.rs
}

\begin{abstract}
Qualitative analysis of liposoluble wheat extract from conventional, integrated, organic, biodynamic and control farming systems was performed by gas chromatography with mass spectrometry (GC-MS). Organic and biodynamic farming systems were close to each other versus conventional and integrated which are similar in fertilization and plant protection. In the control treatment no fertilization or plant protection was used. Cluster analysis (CA) was applied to classify the samples according to lipid profiles in wheat from different farming systems. The obtained results showed that better discrimination of wheat samples was achieved by analyzing the peak area after 18 min retention time (non-saponifiable lipid fraction), than used the peak area for the whole chromatogram. The study has found that this method can be a potentially used for making a distinction between organic and non-organic wheat production.
\end{abstract}

Key words: wheat, farming systems, liposoluble fraction, GC-MS

\section{INTRODUCTION}

Over the past decade, influence of farming systems on food quality has increased interest steadily, especially in terms of the nutritive values and beneficial health effects of food (Bavec et al., 2010). Despite rapid growth of organic food industry in recent time, research comparing the functionality of organic and conventional ingredients is deficient (le et al, 2012). Comparisons of food from organic and conventional systems are often complicated because there is a great variety of environmental and production factors influencing the composition of food (Reganold, 2010). The differences between or- ganic and non-organic production are mainly identified in pesticide use (and residues), type of fertilization, range of food additives, genetic manipulation and selection of technologies (Kahl et al., 2014).

The nutritional value of wheat is especially important because it takes a significant place among the few crop species being extensively grown as food sources (Šramková et al., 2009, Živančev et al., 2009). Cereal lipids, such as essential fatty acids, fat-soluble vitamins, phytosterols with cholesterol-lowering effects have a significant technological and nutritive functional pro- 
perties (Ruibal-Mendieta, 2001). Lipids, whose content is low in common bread wheat $(0.15-0.25 \mathrm{~g} / \mathrm{kg})$, have a significant effect on the quality and the texture of food because of their ability to associate with proteins due to their amphipatic nature and with starch as well, forming inclusion complexes (Šramková et al., 2009).

The studies of Zörb et al. (2006, 2009) showed that differences in concentrations of metabolites (such as sugars, sugar alcohols, amino acids, or organic acids) are pronounced in developing wheat ears of organic and conventional agriculture, but they did not detect extreme differences in metabolite composition and the quality of wheat grains. Vujić et al. (2012) analyzed and compared peak area of lipid compounds of different small grains obtained by GC-MS chromatography using multivariate analyses. Bodroža-Solarov et al. (2014) proposed the same method for extraction of lipids from bread wheat and spelt aiming to differentiate between these cereals. They used modified GC-MS method for liposoluble extract derivatization, focusing on two peak areas: one registered between 12 and 16 min retention time (which separates fatty acids) and the other registered after 16 min (which separates mostly non-saponifable lipids). They found that non-saponifiable lipid fraction is suitable to distinguish between the two different subspecies of wheat.

The development and application of modern analytical techniques allow the authenticity of organic products to be established on the basis of the chemical component profiles. The aim of the study presented in this paper was to determine the possibility of differentiation of types of farming systems by creating dendrograms of liposoluble wheat extracts.

\section{MATERIAL AND METHODS}

\section{Material}

Winter wheat (Triticum aestivum L.) cv. 'Antonius' was grown in 2013 in a longterm field trial at the University Agricultural Centre of University of Maribor in Pivola near Hoče $\left(46^{\circ} 28^{\prime} \mathrm{N}, 1^{\circ} 38^{\prime} \mathrm{E}, 282 \mathrm{~m}\right.$ a.s.l.), Slovenia. The annual mean air temperature of the area is $10.7^{\circ} \mathrm{C}$, and ave- rage annual rainfall in the area is around $1000 \mathrm{~mm}$.

\section{Experimental Plot}

Trial was established on a dystric cambisol (deep) (average $\mathrm{pH}$ value 5.5 in $0.1 \mathrm{KCl}$ solution, soil soluble $P$ of $0.278 \mathrm{~g} / \mathrm{kg}$ and soil soluble $\mathrm{K}$ of $0.255 \mathrm{~g} / \mathrm{kg}$ in top soil layer). Twenty plots $(2.4 \times 7 \mathrm{~m})$ were randomly assigned to five production systems in four replications per system until the year 2007, when the trial has started. The farming systems mostly differed in plant protection and fertilization strategies: conventional farming according to the Slovenian agriculture act and good agricultural practice, integrated farming according to the Slovenian standards for integrated farming, organic farming according to the European Commission Regulation on Organic Farming, and biodynamic farming according to Demeter International Production Standards and European Commission Regulation on Organic Farming. In the control treatment no fertilization or plant protection was used (Bavec et al. 2010). Differences in fertilization and plant protection are presented in detail in Table 1. Wheat was harvested in the middle of July on individual plots and was mixed into two samples. The first sample was a mixture of replications one and two, and the second sample of replications three and four.

\section{Sample preparation}

Ten samples (two from five different farming systems) were milled on a Knifettec 1095 mill into wholegrain flour. After homogenization, about $10 \mathrm{~g}$ of flour from each cultivar was weighed and treated in the following manner. A $12 \mathrm{~mL}$ cuvette for centrifugation was used for pouring $2 \mathrm{~g}$ of flour with a precision of $0.01 \mathrm{~g}$. The cuvette was additionally filled with $10 \mathrm{~mL}$ of $n$-hexane and stirred on a vortex for 2 min, after which the mixture was centrifuged for $5 \mathrm{~min}$, at the speed of 2000 rotations per minute. After this, $3 \mathrm{~mL}$ of clear supernatant was poured into a $10 \mathrm{~mL}$ glass beaker and left to steam up at ambient temperature. From the oily residue an amount of $10 \mu \mathrm{L}$ was taken, reconstituted to $500 \mu \mathrm{L}$ with acetone and additionally $100 \mu \mathrm{L}$ of transesterification reagent added: TMSH (trimethylsulfonium hy- 
Table 1.

Farming systems under investigation in the field trial and differences between them for winter wheat production

\begin{tabular}{|c|c|c|c|c|}
\hline $\begin{array}{l}\text { Production } \\
\text { system }\end{array}$ & $\begin{array}{l}\text { Soil cultivation } \\
\text { and basic } \\
\text { operations }\end{array}$ & Weed management & $\begin{array}{c}\text { Pest } \\
\text { management }\end{array}$ & $\begin{array}{l}\text { Manure } \\
\text { application }\end{array}$ \\
\hline $\begin{array}{l}\text { Conventional } \\
\text { farming } \\
\text { according to } \\
\text { the Slovenian } \\
\text { agriculture act } \\
\text { and GAP }\end{array}$ & $\begin{array}{l}\text { Ploughing, } \\
\text { seedbed } \\
\text { preparation, } \\
\text { sowing, } \\
\text { harvesting }\end{array}$ & $\begin{array}{l}\text { Preventive use of } \\
\text { herbicides } \\
\text { according to GAP, } \\
\text { harrowing when } \\
\text { needed }\end{array}$ & $\begin{array}{l}\text { Preventive use } \\
\text { of pesticides } \\
\text { according to } \\
\text { GAP }\end{array}$ & $\begin{array}{l}\text { NPK and N } \\
\text { mineral } \\
\text { fertilizers } \\
\text { used } \\
\text { according to } \\
\text { GAP and } \\
\text { nutrient } \\
\text { removal } \\
\text { estimates }\end{array}$ \\
\hline $\begin{array}{l}\text { Integrated } \\
\text { farming } \\
\text { according to } \\
\text { Slovenian } \\
\text { standards for } \\
\text { Integrated } \\
\text { farming }\end{array}$ & $\begin{array}{l}\text { Ploughing, } \\
\text { seedbed } \\
\text { preparation, } \\
\text { sowing, } \\
\text { harvesting }\end{array}$ & $\begin{array}{l}\text { Use of herbicides } \\
\text { according to the } \\
\text { rules of INT } \\
\text { management, } \\
\text { harrowing at least } \\
\text { once }\end{array}$ & $\begin{array}{l}\text { Curative use of } \\
\text { pesticides } \\
\text { according to the } \\
\text { rules of INT } \\
\text { management }\end{array}$ & $\begin{array}{l}\text { NPK and N } \\
\text { mineral } \\
\text { fertilizers } \\
\text { used based } \\
\text { on soil } \\
\text { analysis and } \\
\text { nutrient } \\
\text { removal } \\
\text { estimates }\end{array}$ \\
\hline $\begin{array}{l}\text { Organic } \\
\text { farming } \\
\text { according to } \\
\text { the EC } \\
\text { regulation on } \\
\text { Organic } \\
\text { Farming }\end{array}$ & $\begin{array}{l}\text { Ploughing, } \\
\text { seedbed } \\
\text { preparation, } \\
\text { sowing, } \\
\text { harvesting }\end{array}$ & $\begin{array}{l}\text { Harrowing 1-2 } \\
\text { times/season, } \\
\text { cover crops after } \\
\text { cereals }\end{array}$ & & $\begin{array}{l}1.4 \mathrm{LU} \text { of } \\
\text { cattle } \\
\text { manure /ha }\end{array}$ \\
\hline $\begin{array}{l}\text { Biodynamic } \\
\text { farming } \\
\text { according to } \\
\text { Demeter } \\
\text { International } \\
\text { production } \\
\text { standards and } \\
\text { EC regulation } \\
\text { on Organic } \\
\text { Farming }\end{array}$ & $\begin{array}{l}\text { Ploughing, } \\
\text { seedbed } \\
\text { preparation, } \\
\text { sowing, } \\
\text { harvesting }\end{array}$ & $\begin{array}{l}\text { Harrowing 1-2 } \\
\text { times/season, } \\
\text { cover crops after } \\
\text { cereals }\end{array}$ & $\begin{array}{l}\text { Use of } \mathrm{BD} \\
\text { preparations }\end{array}$ & $\begin{array}{l}1.4 \mathrm{LU} \text { of } \\
\text { composted } \\
\text { cattle } \\
\text { manure /ha } \\
\text { with added } \\
\text { BD compost } \\
\text { preparations }\end{array}$ \\
\hline Control plots & $\begin{array}{l}\text { Ploughing, } \\
\text { seedbed } \\
\text { preparation, } \\
\text { sowing, } \\
\text { harvesting }\end{array}$ & $\begin{array}{l}\text { Harrowing 1-2 } \\
\text { times/season }\end{array}$ & none & none \\
\hline
\end{tabular}

GAP - good agricultural practice; INT - integrated farming; EC - Council regulation 834/2007; LU - livestock units; BD - biodynamic

droxide, $0.2 \mathrm{~mol}$ in methanol, MachereyNagel). With such a transesterification reaction, fatty acids from acylglycerol esterify to methyl esters.

\section{GC-MS analysis}

All the testing was conducted on a gaschromatography system. GC-MS analyses were performed using Agilent 5975C 
Series GC-MSD system (7890A GC and $5975 \mathrm{C}$ inert MSD) operating in the $\mathrm{El}$ mode at $70 \mathrm{eV}$, equipped with a HP-5MS capillary column $(30 \mathrm{~m} \times 0.25 \mathrm{~mm}$; film thickness $0.50 \mu \mathrm{m})$. The temperature program was: $50-130{ }^{\circ} \mathrm{C}$ at $30^{\circ} \mathrm{C} / \mathrm{min}$ and $130-300{ }^{\circ} \mathrm{C}$ at $10{ }^{\circ} \mathrm{C} / \mathrm{min}$. The injector temperature was $250{ }^{\circ} \mathrm{C}$. The flow rate of the carrier gas (helium) was $0.8 \mathrm{~mL} / \mathrm{min}$. A split ratio of 1:50 was used for the injection of $1 \mu \mathrm{l}$ of the solutions (Vujić et al., 2012). Liposoluble components of winter wheat were identified using NIST 05 Library.

\section{Statistical analysis}

Descriptive analyses of the data, were performed using the software package STATISTICA 10.0 (StatSoft Inc., Tulsa, OK, USA). All determinations were made in triplicate and all were averaged. Cluster analysis is used to classify objects into groups. To be able to cluster objects, one must measure their similarities. The dissimilarity between two objects is a distance measure. The distance between each pair of clusters is determined, and the two clusters with the smallest distance (largest similarity) are merged. Definitions of distance measures and clustering algorithms can be found in standard chemometric material (Otto, 1999). We used complete linkage and city block (Manhattan) distance. City block distances are measured as the average difference across dimensions of the tested wheat from different production systems. All samples were grouped in a five-dimensional space and two dendograms were formed for different peak areas: an area between 8 and 27 min and after 18 min retention time.

\section{RESULTS AND DISCUSSION}

The same variety of winter wheat from five different production systems (control, conventional, integrated, organic and biodynamic) was examined in this study. The great similarity in the composition of liposoluble components was identified in all types of analyzed samples (Figure 1).

Table 2. lists the liposoluble wheat components which were identified from the chromatogram.

In the study of Vujić et al. (2012), the following liposoluble components of small grains were identified: 2,4-decadienal (isomer), n-tricosane, n-pentacosane, n-hexacosane, n-octacosane, stygmasterol, 22,23-didehydro, 24-metyl-25-homo-cholesterol, beta-tocopherol, all of which differed as compared to the compounds determined in this work.

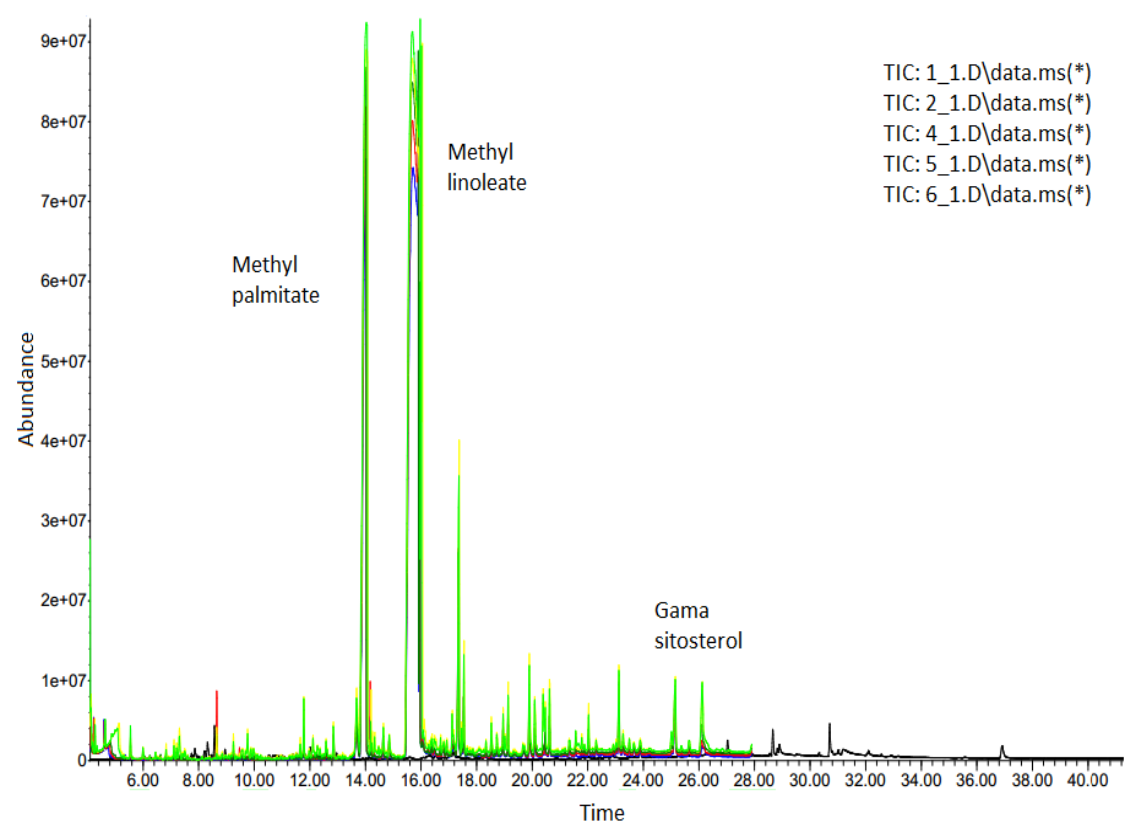

Figure 1. Chromatograms of winter wheat samples from five different production systems (1-control, 2-conventional, 4-integrated, 5-organic and 6-biodynamic) 
Table 2.

Liposoluble components determined in winter wheat samples

\begin{tabular}{cc}
\hline No. & Component \\
\hline 1 & Tetradecane \\
3 & Pentadecane \\
4 & Hexadecane \\
5 & Methyl tetradecanoate \\
6 & Pentadecanoic acid, methyl ester \\
7 & 9-Hexadecenoic acid, methyl ester, \\
8 & Hexadecanoic acid, methyl ester; methyl palmitate \\
9 & Heptadecanoic acid, methyl ester \\
10 & 9,12-Octadecadienoic acid, methyl ester, methyl linoleate \\
11 & 9-Octadecenoic acid, methyl ester; methyl oleate \\
12 & Octadecanioc acid, methyl ester; methyl stearate \\
13 & Eicosanoic acid, methyl ester \\
14 & Docosane \\
15 & Heneicosanoic acid, methyl ester \\
16 & 13-Docosenoic acid, methyl ester \\
17 & Docosanoic acid, methyl ester \\
18 & Tetracosanoic acid, methyl ester \\
19 & Tetracosane \\
20 & Squalene \\
21 & Heptacosane \\
22 & Hexacosanoic acid, methyl ester \\
23 & Heptacosanoic acid, methyl ester \\
24 & Octacosanoic acid, methyl ester \\
& gamma.-Sitosterol \\
\hline
\end{tabular}

The differences in the composition of liposoluble components found in these studies are due to the fact that different materials were investigated in each of them: Vujić et al. (2012) investigated three types of small grains: wheat, triticale and barley whereas this study was based on the same variety of winter wheat originnating from five different production systems. In addition, slightly modified method was applied here. The nature of method modification was that Vujić et al. (2012) used DP-5MS column and methanol to reconstitue the oily residue, while we used HP-5MS capillary column and acetone as solvent. The polarity of the sample has to correspond with the polarity of the stationary phase of the column to increase the resolution and separation. On the other hand, this investigation compared the results in different databases. Here was used NIST 05 Library, while Vujić et al. used Wiley Online Library search.

A dendrogram of wheat samples from different farming systems using complete linkage as an amalgamation rule and the city block (Manhattan) distance as a measure of the proximity between samples is shown in Figure 2. The dendrogram based on GC-MS data registered for the peak area which includes components of the whole chromatogram. The linkage distance (shown on the abscissa axis) between the two main clusters was evident (about 16). As it can be seen the samples are grouped into two branches. The samples from control farming system are separated from the others because no fertilization or plant protection was used. Conventional, integrated, organic and biodynamic farming systems are presented within separate branches with two groups. Gene- 
rally, it is hard to compare more than two different production systems (i.e., four), because some of them are close proximity to each other. Organic farming uses fertilizers and pesticides which are considered natural but it excludes or strictly limits the use of synthetic fertilizers and pesticides, growth regulators, hormones and antibiotics. It is opposite to conventional farming which uses fertilizers and pesticides to achieve higher yield, out of season growth and greater resistance.
Integrated farming system is such that the biological, technical and chemical methods are tuned to take into account the protection of the environment, profitability and social requirements. It is more sustainable agricultural systems compared to the conventional farming. Byodinamic farming system is regarded as a part of the organic system production (Bavec et al. 2010). It emphasizes the use of manures and composts and excludes the use of artificial chemicals on soil and plants.

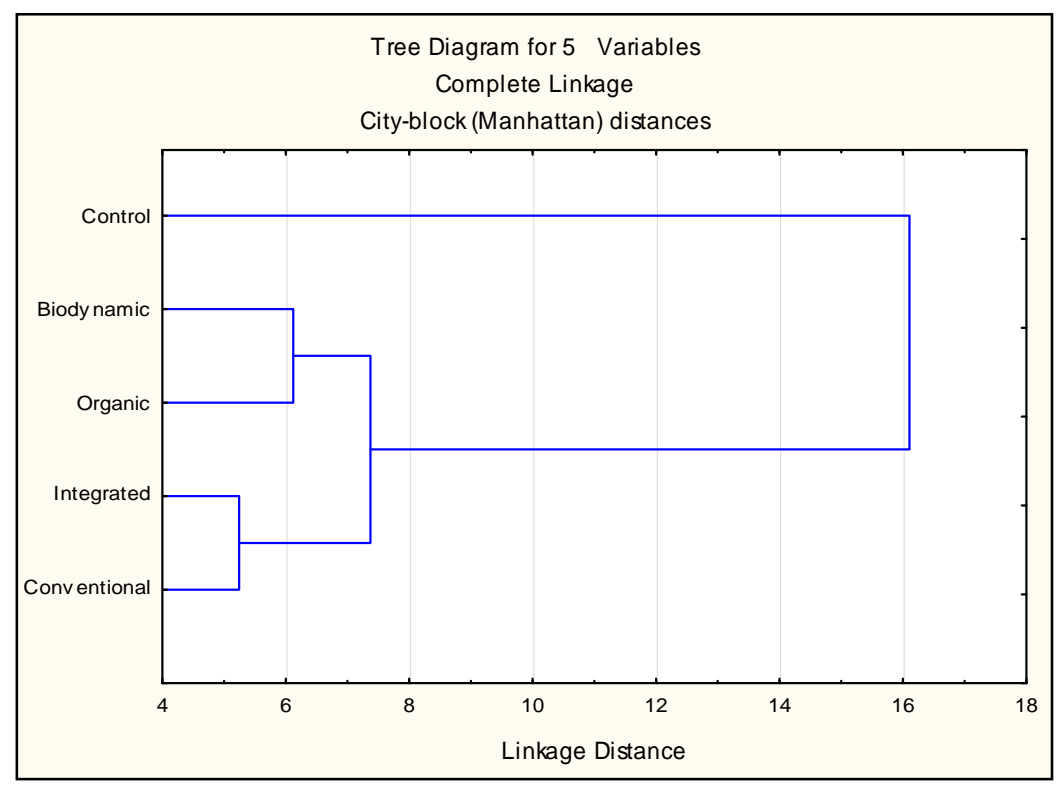

Figure 2. Dendrogram of wheat samples from different farming systems based on the chromatograph data observed in the area between 8 and 27 min retention time

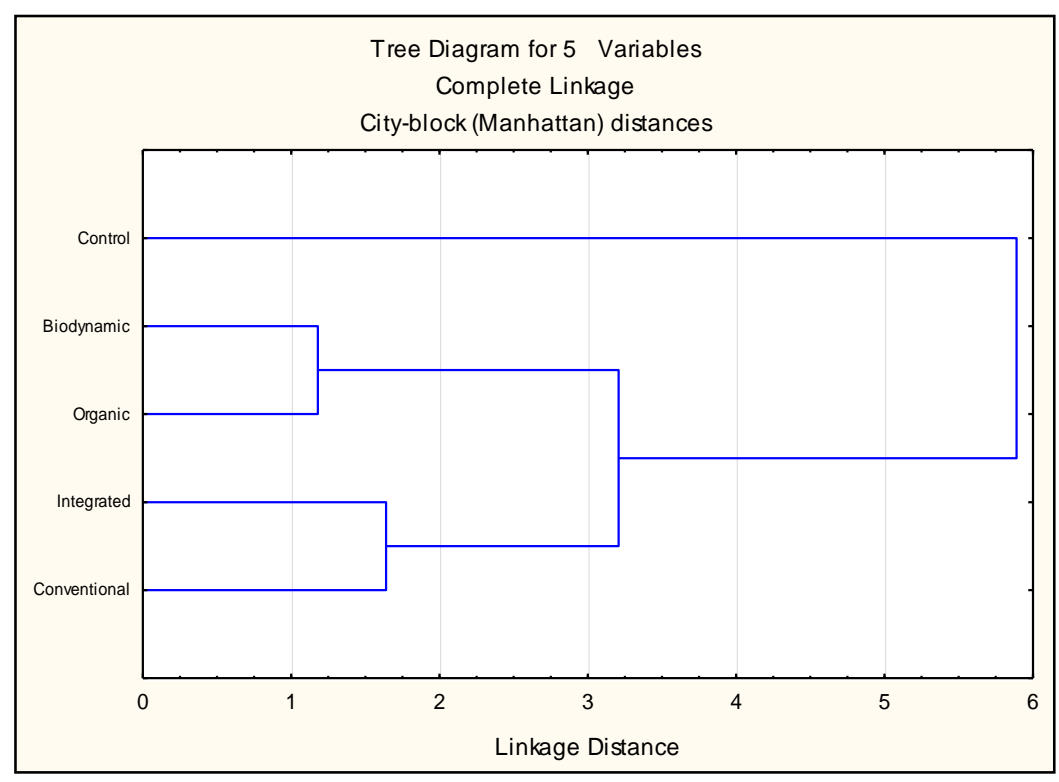

Figure 3. Dendrogram of wheat samples from different farming systems based on the chromatograph data observed in the area after 18 min retention time (non-saponifiable fraction) 
The profile of liposoluble wheat extracts was similar for samples from the conventional and integrated systems, as well as from organic and biodynamic farming systems (Figure 2).

As shown in Table 1, there is similarity in fertilization and plantprotection between the conventional and integrated systems, while organic and biodynamic farming systems are close to each other.

Bodroža Solarov et al. (2014) and Rozenberg et al. (2003) noticed that better discrimination between common wheat and spelt could be achieved comparing the samples based on non-saponifiable lipids. Our study confirmed that larger differences could be observed between different farming systems when comparing components eluted after 18 min retention time (non-saponifiable lipids) (Figure 3). The linkage distance (shown on the abscissa axis) between the tested samples was evident (nearly 6). The city block Manhattan distances between points for the peak area between 8 and $27 \mathrm{~min}$ are greater, as shown on dendrograms, but these distances seem to be more distinctive in the peak area after $18 \mathrm{~min}$.

Better segmentation of results was achieved for the peak area registered after 18 min retention time, which indicates that GC-MS analysis of non-saponifiable lipids provides the ability for proper distinction between the samples from different farming systems.

\section{CONCLUSION}

Consumers' interest in organic products is increasing and it requires robust analytical tools for their authentication. An implication of this study is the possibility of comparing types of farming systems against the lipid content applying GC-MS chromatography and multivariate statistical techniques. This is a potentially useful tool to distinguish between products coming from different production systems.

\section{ACKNOWLEDGEMENTS}

This paper is a result of the research within the project III 46005 "Novi proizvodi cerealija i pseudocerealija iz organske proizvodnje (New products based on cereals and pseudocereals from organic production)", financed by the Ministry of Education, Science and Technological Development, Republic of Serbia.

\section{REFERENCES}

1. Bavec, M., Turinek, M., Grobelnik-Mlakar, S., Slatnar, A., Bavec, F. (2010). Influence of Industrial and Alternative Farming Systems on Contents of Sugars, Organic Acids, Total Phenolic Content, and the Antioxidant Activity of Red Beet (Beta vulgaris L. ssp. vulgaris Rote Kugel). Journal of Agricultural and Food Chemistry, 58, 11825-11831.

2. Bodroža-Solarov, M., Vujić, Đ., Ačanski, M., Pezo, L., Filipčev, B., Mladenov, N. (2014). Characterization of the liposoluble fraction of common wheat (Triticum aestivum) and spelt ( $T$. aestivum ssp. spelta) flours using multivariate analysis. Journal of the Science of Food and Agriculture. doi: 10.1002/jsfa.6655.

3. le, P. S., Petros, D., Stinner, D. H., Phelan, P. L., Hamaker, B., Koelling, K.W., Vodovotz, Y. (2012). Comparison of the Gelatinization Behavior of Organic and Conventional Spelt Starches Assessed by Thermal and Rheological Analyses. Journal of Agricultural and Food Chemistry, 60 (36), 9229-9235.

4. Kahl, J., Bodroža Solarov, M., Busscher, N., Hajslova, J., Kneifel, W., Kokornaczyk, M. O., van Ruth, S., Schulzova, V., Stolz, P. (2014). Status quo and future research challenges on organic food quality determination with focus on laboratory methods. Journal of the Science of Food and Agriculture, doi: 10.1002/jsfa.6553.

5. Otto, M. (1999). Chemometrics statistics and computer application in analytical chemistry. Weinheim, Germany: Wiley-VCH.

6. Reganold, J.P., Andrews, P.K., Reeve, J.R., Carpenter-Boggs, L., Schadt, C. W., Alldredge, J. R., Ross, C. F., Davies, N.M., Zhou, J. (2010). Fruit and Soil Quality of Organic and Conventional Strawberry Agroecosystems. PLOS ONE 5 (9), e12346. doi:10.1371/journal.pone.0012346.

7. Rozenberg, R., Ruibal-Mendieta N. L., Petitjean, G., Cani, P., Delacroix, D. L., Delzenne N.M. et al. (2003). Phytosterol analyses and characterrization in spelt (Triticum aestivum ssp. Spelta L.) and wheat (T.aestivum L.) lipids by LC/APCI. Journal of Cereal Science, 38: 189-197.

8. Ruibal-Mendieta, N. L., Delacroix, D. L., Meurens, M. (2002). A Comparative Analysis of Free, Bound and Total Lipid Content on Spelt and Winter Wheat Wholemeal. Journal of Cereal Science, 35(3), 337-342.

9. STATISTICA (Data Analysis Software System) (2012). v.12.0., Stat-Soft, Inc., USA (www.statsoft.com).

10. Šramková, Z., Gregováb, E., Šturdíka E. (2009). Chemical composition and nutritional quality of 
wheat grain. Acta Chimica Slovaca, 2 (1), 115138.

11. Vujić, Đ., Ačanski, M., Bodroža-Solarov, M., Hristov, N., Krunić, M. (2012). Performance of GC-MS analysis for differentiation of various types of flour by creating dendogram of liposoluble extract. Chemical Industry Chemical Engineering Quarterly, 18 (4), 555-561.

12. Zörb, C., Langenkämper, G., Betsche, T., Niehaus, K., Barsch, A. (2006). Metabolite Profiling of Wheat Grains (Triticum aestivum L.) from Organic and Conventional Agriculture. Journal of Agricultural and Food Chemistry, 54 (21), 8301-8306.
13. Zörb, C., Niehaus, K., Barsch, A., Betsche, T., Langenkämper, G. (2009). Levels of Compounds and Metabolites in Wheat Ears and Grains in Organic and Conventional Agriculture. Journal of Agricultural and Food Chemistry, 57 (20), 9555-9562.

14. Živančev, D., Torbica, A., Mastilović, J., Hristov, N. (2009). Technological quality of wheat cultivars from new breeding program (ZVEZDANA and NS3-5299/2) and comparison to the technological quality of wheat cultivars commonly used in agricultural practice (NS RANA 5, LJILJANA, POBEDA AND EVROPA 90), Food Processing, Quality and Safety, 3-4, 53-58.

\section{МОГУЋНОСТ ПОТВРЪИВАҢА АУТЕНТИЧНОСТИ ОРГАНСКЕ ПШЕНИЦЕ ПРИМЕНОМ ГАСНЕ ХРОМАТОГРАФИЈЕ СА МАСЕНОМ CПEКТРОМЕТРИЈOM}

Јелена А. Круљ ${ }^{* 1}$, Јована С. Бркљача ${ }^{1}$, Иван Љ. Миловановић ${ }^{1}$, Силва А. Гробелник Млакар ${ }^{2}$, Мартина Бавец ${ }^{2}$, Франц Бавец ${ }^{2}$, Марија И. Бодрожа Соларов

${ }^{1}$ Универзитет у Новом Саду, Научни институт за прехрамбене технологије у Новом Саду, 21000 Нови Сад, Булевар цара Лазара бр. 1, Србија

${ }^{2}$ Универзитет у Љубљани, Биотехнички фракултет, Департман за пољопривреду, Катедра за воћарство, винарство и повртарство, Љубљана, Јамникаријева 101, Словенија

Сажетак: За квалитативну анализу липосолубилног екстракта пшенице добијене конвенционалним, интегрисаним, органским, биодинамичким и контролним системима производње, коришћена је гасна хроматографија са масеном спектрометријом. У погледу примењених агротехничких мера, постојала је сличност између конвенционалног и интегрисаног пољопривредног система, као и између органског и биодинамичког система. За узорке пшенице са контролног система није примењено ђубрење, као ни третмани заштите биља. Класификација узорака према липидним фракцијама пшенице узгајане на различитим пољопривредним системима је вршена помоћу кластер анализе. Добијени резултати показују да се боља диференцијација узорака постиже анализом области пикова за ретенциона времена после 18 мин (неосапуњива липидна фракција), у односу на анализу површине пикова за цели хроматограм. Резултати указују да овај метод има потенцијал за контролу аутентичности органских производа и да треба наставити истраживања у правцу развоја овог метода.

Кључне речи: пшеница, пољопривредни системи производње, липосолубилна фрракција, GC-MS

Received: 1 August 2014. 